\title{
NUTRITION AS THE MAIN FACTOR TO PROTECT THE STATE OF HEALTH AND THE LIFE PROVISION OF HUMAN ORGANISM
}

\author{
G. Simakhina, N. Naumenko \\ National University of Food Technologies
}

\begin{tabular}{l}
\multicolumn{1}{c}{ Key words: } \\
Nutrition \\
Health \\
Functional foodstuffs \\
Gerontology \\
Life quality \\
\hline
\end{tabular}

Article history:

Received 09.07.2018

Received in revised form

27.07.2018

Accepted 15.08.2018

Corresponding author:

G. Simakhina

E-mail:

npnuht@ukr.net

\begin{abstract}
The article gives an analysis of some cardinal problems connected with place and role of healthy nutrition in improving state of health in people of different age and profession. There was mentioned that, for the last years, the tendency to raise the quantity of crucially new foodstuffs destined to prevent various diseases, to increase the immunity, and to lower the risks of intoxications and bad economical effects has been being prevalent.

The authors of the article have consequently proved the requirement, actual for scientists and consumers - to apprehend the new approaches and tendencies in creating the new foodstuffs and to implement them into Ukrainian food industry. These products may be called differently (healthy, functional, or special foods); meanwhile, despite the term, their essence is evident - protection of human organism from malignant environmental factors, improvement of health state, increasing of adaptive potentials, and providing longevity.

The modern world market of food production can be characterized by rapid development of a segment of new foodstuffs destined to regulate functioning of all organs and systems of an organism: innovative food prepared either by new technologies or from novel raw materials (novel food); ready-to-eat food; food with special destinations (functional food); healthy food. Therefore, food industry gets transformed into the important component of human health protection and subsequently occupies its priority place in formation of intellectual potential and social activity of man.

The new generation of foodstuffs corresponds to the requirement of modern nutritiology — particularly, necessity to provide all of the population strata with available healthy (functional) foodstuffs, because state of health is directly dependent on the structure and quality of nutrition.
\end{abstract}

DOI: $10.24263 / 2225-2924-2018-24-4-23$ 


\title{
ХАРЧУВАННЯ ЯК ОСНОВНИЙ ЧИННИК ЗБЕРЕЖЕННЯ СТАНУ ЗДОРОВ'Я ТА ЖИТТЕЗАБЕЗПЕЧЕННЯ ОРГАНІЗМУ ЛЮДИНИ
}

\author{
Г.О. Сімахіна, Н.В. Науменко \\ Національніий університет харчових технологій
}

У статті розглянуто основні проблеми, пов'язані з місцем і роллю здорового харчування у поліпшенні стану здоров'я людей різного віку та професії. Зазначено, що в останні роки на світовому ринку нових технологій і харчових продуктів визначилася тенденція до збільшення кількості якісно нових продуктів, призначених для запогігання різним захворюванням, зміцнення захисних сил організму, зниження ризику впливу токсичних сполук і несприятливих економічних чинників.

Автори статті послідовно обтрунтовують актуальну для науковців та споживачів потребу - засвоїти $i$ впровадити в харчову промисловість України нові підходи й нові світові тендениії до створення продуктів, щэо їх сьогодні називають по-різному (оздоровчими, функиіональними, спеціальними). Та, незважаючи на терміни, сутність таких продуктів одна - захист організму людини від несприятливих чинників довкілля, поліпшення стану здоров'я, підвищення адаптаиійних можливостей, подовження тривалості життя.

Характерною ознакою сучасного світового ринку харчової продукиії $\epsilon$ стрімкий розвиток сегментів нових харчових продуктів, призначених для поліпшення функиіонування всіх органів та систем організму людини: інноваційних харчових продуктів, виготовлених за новітніми технологіями або з нової сировини (novel food); готових до вживання продуктів (ready-to-eat); продуктів спеціального призначення, або функиіональних продуктів (functional food); оздоровчих продуктів (healthy food). Харчова промисловість перетворюється на важливу складову системи охорони здоров'я людини і посідає пріоритетне місие у формуванні ї̈ інтелектуального потениіалу та соиіальної активності.

Нове покоління харчових продуктів відповідає вимогам сучасної нутриціології-необхідності забезпечити всі верстви населення доступними оздоровчими (функціональними) продуктами, оскільки стан здоров'я людини безпосередньо залежить від структури і якості харчування.

Ключові слова: харчування, здоров'я, функиіональні продукти, геронтологія, якість життя.

Постановка проблеми. Підвищення захворюваності серед населення нерозривно пов'язано з нераціональним харчуванням, адже серед чинників, що формують здоров'я людини, на харчування припадає 40-45\% [1]. Сучасне ставлення до харчування - це обгрунтований вибір споживачами тих харчових продуктів, які $є$ корисними для здоров'я і забезпечують організм фізіологічно необхідними компонентами. 
Незважаючи на те, що харчові продукти завжди виконували функцію забезпечення людини необхідними макро- та мікронутрієнтами, сьогодні до обігу введено поняття «функціональні харчові продукти», які, завдяки наявності функціональних інгредієнтів, що позитивно впливають на здоров'я людини, здатні заповнити в харчуванні дефіцит відповідних речовин, сприяти нормалізації усіх функцій органів та систем організму людини.

У Міжнародному інституті наук життя (Норвегія) сформульоване робоче визначення функціональних продуктів: харчові продукти відносять до функціональних, якщо вони, крім адекватного харчового ефекту, демонструють сприятливу дію на одну або декілька заданих функцій організму таким чином, щоб стан здоров'я поліпшився і /або знизився ризик захворювання.

Основним призначенням харчових продуктів можна вважати, окрім надходження необхідних нутрієнтів, зміцнення стану здоров'я людини. З'явилося поняття функціональних харчових продуктів в Японії для популярних там продуктів «Tokutci Hohenyo Shokuhin» і означало: харчові продукти, які, поряд 3 харчовим та фізіологічним значенням, приносять і терапевтичну користь [2;3].

Фахівці розглядають сьогодні харчові продукти у новій якості - як носії біологічно активних речовин (БАР), що беруть участь у всіх процесах фiзioлогічної та гормональної регуляції організму людини [4]. Вони є певною мірою (залежно від кількісного та якісного складу БАР) лікувальними, профілактичними, спеціальними тощо. Призначення лікувально-профілактичних та оздоровчих продуктів із підвищеним вмістом БАР полягає у запобіганні чи відновленні метаболічних порушень в організмі під впливом на нього шкідливих чинників довкілля.

У тих екстремальних умовах, у яких нині перебуває переважна частина населення України, харчові продукти, що виробляються вітчизняною промисловістю, повинні: компенсувати дефіцит біологічно активних компонентів, що виникає під впливом несприятливих чинників довкілля; покращувати функціональний стан органів та систем організму; поліпшувати захисні функції імунної системи організму; підвищувати фізичну спроможність, сприяти посиленню адаптаційних резервів організму і психологічної стійкості в екстремальних ситуаціях; прискорювати процеси відновлення метаболічних процесів після підвищених екологічних, фізичних, нервово-емоційних навантажень; покращувати самопочуття.

Сукупність названих властивостей свідчить про можливість істотної перебудови метаболічних процесів в організмі за допомогою спеціально підібраної структури харчування [5].

Аналіз останніх досліджень і публікацій. На думку М.Г. Холодного, відомого українського ботаніка та мікробіолога, вченого-натураліста XX століття, людина перебуває не над Природою, а всередині неї [6]. Вона органічно пов'язана з Природою всім своїм складним єством і діє на неї не ззовні, а зсередини.

Протягом життя організм людини змушений пристосовуватися до умов довкілля та їх змін: нестачі кисню і вологи в повітрі, різких перепадів температури, сильної ультрафіолетової радіації, надзвичайної яскравості денного 
світла. Все це супроводжується значними фізичними навантаженнями та великим психологічним напруженням.

Наприклад [7], на висоті через брак кисню знижується слиновиділення, слабшає діяльність всіх травних залоз, жовчоутворення, виділення соку підшлунковою залозою, порушується всмоктування жирів, погіршується перистальтика кишок; висока температура прискорює розвиток вітамінної недостатності, оскільки вітаміни, особливо водорозчинні ( $\mathrm{B}_{1}, \mathrm{~B}_{2}, \mathrm{~B}_{6}, \mathrm{C}$ і РP), виділяються 3 організму 3 потом; а низькі температури провокують збільшення витрат тепла організмом.

Пристосування організму до природних явищ не завжди відбувається швидко і безболісно, а головне, не завжди компенсується негативний вплив природних чинників на людину. Саме тому в екстремальних умовах необхідним є повноцінне збалансоване правильне харчування, що забезпечить надходження до організму харчових речовин, здатних компенсувати негативний вплив чинників навколишнього середовища [8].

Вживання функціональних продуктів гарантує усунення неповноцінності харчування, поповнення організму необхідними компонентами, а також послаблення токсичних впливів елементів, які або присутні в продукті, або утворюються в самому організмі. Функціональні продукти входять до раціону населення у всьому світі. Деякі країни Свропи виділяють державну дотацію на збагачення харчових продуктів різними дієтичними добавками.

Отже споживання функціональних продуктів можна вважати одним із найбільш діючих і економічно обгрунтованих шляхів корекції наявного дефіциту необхідних речовин в екстремальних умовах життєдіяльності. Тому метою цього дослідження $є$ узагальнення та систематизація сучасних даних щодо органічного, багатогранного і безпосереднього зв'язку харчування та стану здоров’я людини.

Матеріали і методи. У статті здійснено аналіз літературних джерел вітчизняних та зарубіжних учених, сформульовано власні умовиводи з розроблення оздоровчих продуктів. Сформульовано концепцію здорового харчування.

Викладення основних результатів дослідження. Створення нового покоління харчових продуктів і введення їх до раціону споживачів $\epsilon$ істотною видозміною структури харчування, що традиційно склалась для кожного народу. Тобто, з одного боку, необхідність виробництва інноваційних харчових продуктів $є$ реальною потребою сучасності, а 3 іншого - воно вимагає подолання певних стереотипів у харчових уподобаннях, більш високого рівня культури харчування і адаптації організму людини до нових харчових продуктів та інгредієнтів.

Тому конструювання, виробництво та споживання нових харчових продуктів може здійснюватись лише на підставі науково обгрунтованих і перевірених практикою медико-біологічних принципів, нових технологій перероблення сільськогосподарської та лікарської сировини на оздоровчі продукти і гарантією абсолютної безпеки такої продукції для споживачів.

Для вирішення усіх цих питань потрібно мати грунтовні знання, тому що саме в галузі оздоровчих продуктів проводяться найбільш інтенсивні дослідження, саме галузь оздоровчих продуктів зараз розвивається найбільш 
швидкими темпами і на світовому ринку саме оздоровчі продукти мають найбільший попит.

При розробленні нових харчових продуктів слід мати на увазі, що людина це система, що живе у тісній взаємодії з Природою. Незважаючи на істотні особливості створеного нею життєвого середовища, людина продовжує бути невід'ємною частиною космосу, повністю підпорядкованою діючим у ньому законам. Саме в людині жива природа досягла ступеня еволюції, на якому в іiі існуванні та подальшому розвитку починають набирати панівного значення розум, воля та моральні ідеали. Розум дає людині можливість передбачити наслідки своїх вчинків, а воля — спрямувати їх у напрямі поставленої мети [9].

Найбільш тісним, органічним, багатогранним зв'язком людини з Природою є харчування. Це та основа, на якій грунтується вся іiі творча діяльність, звідки людина бере все необхідне для нормального функціонування і підтримання належного стану здоров'я, для реалізації себе в житті.

Видатний сучасний фізіолог та геронтолог, всесвітньовідомий учений, що розробив теорію та практику антистаріння, академік НАН України В.В. Фролькіс вважав, що геронтологія - не реанімація, не подовження життя будьякою ціною, в будь-якому стані [10]. Мета геронтології не лише в кількості прожитих років, а й у якості життя, зміст же його - в душевному та фізичному комфорті, у прагненні до високого.

Саме показник якості життя за останні роки одним із основних застосовується в різних країнах при оцінюванні ефективності використання ресурсів охорони здоров'я та благополуччя населення. Група експертів Всесвітньої організації охорони здоров’я (ВООЗ) визначила: «Якість життя - ие спосіб життя в результаті комбінованої дї чинників, щчо впливають на здоров'я, щзастя, включаючи індивідуальне благополуччя в навколишньому фізичному середовищі, задовільну роботу, освіту, соичіальний успіх, а також свободу, можливість вільних дій, справедливість і відсутність будь-якого гніту». Для визначення стану організму людини академік М.М. Амосов запропонував також показник «кількості здоров’я», вважаючи, що визначення здоров’я лише як комплексу нормальних показників недостатньо: «Науковий підхід до поняття здоров'я повинен бути кількісним» [11].

Несприятлива екологія, забрудненість повітря, води, грунтів, а основне, низька біологічна та харчова цінність сучасних харчових продуктів, збіднених на вітаміни і мінеральні солі, вирощених у неприродних умовах 3 використанням плівкових покриттів, мінеральних добрив і хімічних засобів боротьби 3 бур'янами та шкідниками, призвели до значного погіршення стану здоров'я людини. Різке зниження рухової активності, численні джерела низькочастотних випромінювань (екрани комп'ютерів та телевізорів), шкідливі звички (паління, алкоголь, наркотики), життєві складності, стреси справляють більш руйнівну дію на організм людини, знижуючи імунітет, порушуючи обмін речовин, викликаючи різні захворювання. Саме ці чинники руйнують людський організм, призводять до передчасної старості та смерті. Вони негативно впливають на роботу мозку, який, складаючи всього 5\% від маси тіла, споживає понад 20\% кисню, що використовується організмом, 20...30\% загального числа калорій та левову частку всієї глюкози, що міститься в крові. 
Тому, намагаючись підтримати нормальний стан здоров'я, відновити клітини головного мозку і нервової системи, ми часто шукаємо порятунку в ліках, тим паче що сьогодні їх не бракує. Негативні ефекти й парадоксальні реакції організму на фармакологічні речовини спонукають до пошуку нових засобів відновлення здоров'я і підтримання його на належному рівні.

Двічі лауреат Нобелівської премії, лауреат усіх найпрестижніших світових нагород в галузі хімії, біології, медицини, американець Лайнус Полінг був переконаний, що людина може продовжити своє життя на 25 і навіть на 35 років, якщо вже замолоду споживатиме необхідну кількість різних харчових біологічно активних речовин, передусім вітамінів: «Необхідною умовою хорошого здоров'я є наявність потрібних молекул у потрібній кількості, в потрібному місці людського тіла, в потрібний час» [12].

Тому слід віддати данину мудрості і спостережливості відомого сучасного психолога В. Леві, котрий дуже точно й влучно схарактеризував основні етапи розвитку системи нашого харчування, назвавши цей історичний процес гігантським харчовим експериментом. Отож, за В. Леві, вся історія нашого харчування - це експеримент. Гігантський безперервний експеримент [13]. Розпочатий разом із виникненням людства на землі, близько мільярда років тому, продовжуваний кожним народженим, а тому має усі шанси на вічність. Це нашим продуктам ми зобов'язані фантастичною витривалістю свого організму, здатного нейтралізувати різноманітні отрути, навіть використовувати деякі з них як ліки.

Цей великий харчовий експеримент людства можна розділити на три головні періоди: перший - природний. Експеримент еволюції. Тривав сотні мільйонів років. У результаті було створено людський організм у його нинішньому вигляді; другий - історичний, культуральний. Експеримент цивілізації. Тривав близько кількох тисячоліть. У результаті було створено культуру, зокрема й культуру харчування; третій період розпочався порівняно недавно, хоча передумови його склались у минулі часи. Період свідомий. Експеримент науки, технології і медицини. В результаті його має бути створено таке харчування, яке стане людині і ліками, тобто ідеальне харчування.

Відповідно до цих періодів протягом тисячоліть змінювались уявлення про те, як правильно харчуватись. Разом $з$ цим завжди існувала мрія про ідеальну їжу, котра містила б лише корисні сполуки та сприяла людині у їі вдосконаленні (думки про ідеальну їжу можна виявити уже в класичній грецькій міфології). Особливо актуальною ця мрія стала в нашому столітті, коли людина так часто вступає у конфлікт із природою.

Таким чином, спочатку мрія, а потім наукова ідея про ідеальну їжу та ідеальне харчування набирали все більшої популярності з багатьох причин, гуманістичне, соціальне та наукове знання яких очевидне.

Ідея ідеальної їжі та ідеального харчування в цілому грунтується на строгих наукових постулатах. В науковій формі іiі розвинуто на базі класичної теорії, що отримала назву теорії збалансованого харчування, сформованої під впливом робіт визначних учених, починаючи з Лавуазьє і Гельмгольца [1]. 
Головне положення цієї теорії полягає в тому, що харчування — це процес підтримання та врівноваження молекулярного стану організму, тобто процес поповнення тих витрат, які відбуваються в організмі у зв'язку із основним обміном, витратами енергії при роботі, при рості молодого організму тощо. В результаті перетравлювання і поглинання різних харчових сполук 3 них вилучаються необхідні компоненти. Співвідношення харчових сполук, що надходять в організм у вигляді певного раціону, має бути добре збалансованим. При цьому існує рівновага між кількістю і спектром речовин, що надходять і витрачаються. За допомогою спеціальних внутрішніх механізмів така рівновага підтримується дуже точно.

На сучасному етапі знань медицини, біології, фізіології поняття про ідеальну їжу трансформувались у цілком реальне харчування, що поряд із необхідними поживними компонентами містить сполуки, які визначають стан здоров'я людини, іiі імунітет, здатність до адаптації, а також можливість протистояти різноманітним негативним зовнішнім і внутрішнім чинникам.

Саме тому останнім часом все більшої популярності набувають харчові продукти оздоровчого і профілактичного призначення, збагачені вітамінами, незамінними амінокислотами, мікро- та макроелементами, іншими біологічно активними речовинами. Завдяки таким продуктам людина може зберегти своє здоров'я, повністю задовольнити фізіологічні потреби в енергії та харчових сполуках, котрі використовуються організмом для побудови клітин, органів і тканин [14].

Термін «оздоровчі, функціональні харчові продукти» поступово стає зрозумілим та звичним. Ми - сучасники - взагалі полюбляємо слова, які точно відбивають стиль життя: функціональний одяг, функціональні прилади - це зрозуміло, чітко, сучасно. Чому б урешті-решт не застосувати такий підхід і до «хліба насущного»? Спершу японці, потім американці й дещо пізніше європейці досягли цього висновку: продукти мають бути функціональними, оздоровчими, тобто забезпечувати необхідну умову виживання у нашому нинішньому середовищі. Такою умовою $є$ належний стан здоров'я.

Саме здоров'я (висловлюючись мовою математичних величин) і $є$ власне функція - залежна, змінна величина, яка змінюється відповідно до зміни іншої величини — аргументу, у нашому разі - харчових продуктів [15]. На цьому математичному рівні усе відносно просто: зміни «в часі, в структурі» харчових продуктів (їхнього складу, якості, безпеки) спричинюються до змін (як позитивних, так і негативних) у залежному від них стані здоров'я.

Але $\epsilon$ інший, біологічний сенс розуміння поняття «функція», пов'язаний зі специфічною діяльністю живого організму, його органів, тканин і клітин. У цьому розрізі термін «функціональний» нерозривно пов'язаний із фізіологією харчування - розділом нутриціології, який вивчає харчові речовини та компоненти їжі, їхню дію та взаємодію, метаболізм і роль у підтриманні здоров'я або виникненні захворювань. Нехтування цього аспекту виключає створення продукту, який відповідає визначенню «функціональний».

Сьогодні ця категорія продуктів користується найбільшим попитом. За офіційними даними, у 2016 р. 78\% американських споживачів зупиняли вибір на збагачених продуктах. Порівняно з 2015 р., їхня кількість зросла на 35\%. 
Аналіз американського ринку функціональних харчових продуктів у 2001 p. та тенденції його зміни до 2016 р. свідчить про те, що основною групою у структурі функціональних продуктів залишаться напої та продукти на основі зернових. Решта продуктів - готові сніданки, снеки та молочні продукти [16].

Український ринок оздоровчих продуктів поступово заповнюється не лише імпортними, а й вітчизняними продуктами, до числа яких входять кисломолочні продукти, різноманітні напої, збагачені вітамінами, мінеральними речовинами та розчинними харчовими волокнами. Він також включає хлібобулочні вироби, готові сніданки, кондитерські вироби. 3'явилися вітчизняні жирові продукти покращеного жирно-кислотного складу за рахунок збагачення їх джерелами поліненасичених жирних кислот, вітамінізовані [17].

Результати останніх досліджень нутриціології дали можливість виявити кореляційну залежність між вмістом у продуктах окремих нутрієнтів та станом здоров'я населення. I це дозволило сформувати новий погляд на їжу як на засіб профілактики та допоміжний засіб при лікуванні багатьох захворювань [18]. На основі цього висновку провідні вчені світу сформулювали концепцію оздоровчого, функціонального харчування, і на нинішньому етапі розвитку суспільства починає розвиватись нова наукова дисципліна функціональна нутриціологія, або фармаконутриціологія. Безумовно, один із основних напрямів розвитку цієї науки має бути пов'язаним із оздоровчим харчуванням.

3 нашої точки зору, концепція оздоровчого харчування - це сукупність поглядів та взаємопов'язаних потоків знань (як нових, так і вже осмислених наукою) щодо єдності усіх різноманітних функцій, які утворюють велику систему людина-харчування-здоров'я, і визначають основні напрями, стратегію, тактику створення нових продуктів профілактичної та оздоровчої дії, адекватних потребам людини.

Для створення в Україні індустрії оздоровчого харчування, для забезпечення усіх верств населення, незалежно від їхнього матеріального добробуту, функціональними продуктами, для практичної реалізації концепції оздоровчого харчування доцільно в практичних умовах промислового виробництва керуватись світовим досвідом створення оздоровчих продуктів.

\section{Висновки}

Наукові відкриття XX-XXI століття дали змогу створити атомну енергетику, швидкісні транспортні мережі, нові біологічні, радіаційні, лазерні, фармацевтичні та харчові технології, з'ясувати геном людини і таємниці психіки. Разом з тим, на тлі величезних досягнень виникло багато несподіваних проблем зі здоров'ям людей, пов'язаних із технічним прогресом, екологією, структурою харчування тощо [19].

Сучасний спосіб життя 3 характерним для нього надлишком у раціоні калорійної їжі, недостатнім вживанням фруктів, овочів, харчових волокон, гіподинамією і стресами призвів до появи нових та різкого зростання відомих захворювань. У ї переліку з'явився термін «хвороби цивілізації»: синдром хронічної втоми, атеросклероз, ожиріння, серцево-судинні, ендокринні, онкологічні та інші захворювання. 
Відповідно до основних періодів розвитку людства змінювались уявлення про правильне харчування. Завжди існувала мрія про ідеальну їжу, котра містила б лише корисні сполуки та сприяла людині у іiі вдосконаленні. На сучасному етапі знань медицини, біології, фізіології поняття про ідеальну їжу трансформувались у цілком реальне харчування - оздоровче, яке, поряд із необхідними поживними компонентами, містить сполуки, що визначають стан здоров'я людини.

На сьогодні незаперечним є одне - розвиток людини (фізичний та психіч-

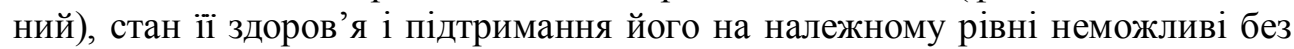
раціональної взаємодії людини і природи, без уміння людини розумно використати потенційні можливості сільськогосподарської та лікарської сировини та створити на ії основі нове покоління продукції - оздоровче харчування.

Знання про здоров'я людство накопичувало протягом тисячоліть. Цей процес продовжується і досі. І можливо, саме сучасний етап розвитку - це час об'єднати, зібрати всі знання про Людину і використати їх на благо коеволюції Людини і Природи. I доцільно згадати слова Авіценни: «Той, хто здобуває знання про первозданне, у повній відповідності з Аристотелем здобуває заново нову натуру».

Щоб найбільш ефективно використати найтісніший зв'язок людини і природи, необхідним є розроблення харчових продуктів принципово нового покоління. Для вирішення цієї проблеми потрібно: по-перше, підготувати висококваліфіковані кадри, здатні об'єднати сучасні технологічні процеси 3 фізіологією і фармакологією харчування для конструювання нових продуктів 3 високою функціональною активністю; по-друге, створити вітчизняну індустрію здорового харчування, докорінно реконструювавши підприємства харчової промисловості й оснастивши їх потрібною технікою; по-третє, розробити і впровадити економічно вигідні технології виробництва продуктів як масового споживання, так і спеціального призначення.

\section{Література}

1. Гігієна харчування 3 основами нутриціології: підручник / В.І. Ципріян та ін. Київ : Здоров'я, 2007. - 565 с.

2. Капрельяни Л.В. Функціональні продукти : монографія / Л.В. Капрельянц, К.Г. Іоргачова. - Одеса : Друк, 2003. - 312 с.

3. Капрельянц Л.В. Лікувально-профілактичні властивості харчових продуктів та основи дієтології / Л.В. Капрельянц, А.П. Петросьянц. — Одеса : Друк, 2011. - 260 с.

4. Сімахіна Г.О. Концепція оздоровчого харчування та шляхи їі реалізації / Г.О. Сімахіна // Наукові праці Національного університету харчових технологій. — 2010. № 33.- С. $23-26$.

5. Гулий І.С. Основи валеології. Валеологічні аспекти харчування : Підручник / I.С. Гулий, Г.О. Сімахіна, А.І. Українець. - Київ. : НУХТ, 2003. — 336 с.

6. Холодный Н.Г. Мысли натуралиста о природе и человеке [Электронный ресурс] / Н.Г. Холодный. — Режим доступа : www.nffedorov.ru/mbnff/biblio/knigi/antrukos/holl.htm.

7. Личак I.C. Методичні рекомендації щодо організації харчування у туристських походах / І.С. Личак. - Біла Церква, 2010. - 56 с.

8. Тутельян B.A. Микронутриенты в питании здорового и больного человека / В.А. Тутельян, В.Б. Спиричев, Б.П. Суханов, В.А. Кудашева. — Москва : Колос, 2002. — 424 с. 
9. Азимов А. Путеводитель по науке. От египетских пирамид до космических станций / Айзек Азимов ; пер. с англ. - Москва : ЗАО «Центрполиграф», 2005. - 788 с.

10. Фролькис B.В. Долголетие : действительное и возможное / В.В. Фролькис. Київ : Наукова думка, 1989. — 244 с.

11. Амосов Н.М. Энциклопедия Амосова. Алгоритм здоровья. Человек и общество / Н.М. Амосов. - Донецк : Сталкер, 2003. - 464 с.

12. Полинг Л. Вся жизнь в борьбе за мир. Диалог / Л. Полинг, Д. Икеда; пер. с англ. Ю.М. Канцура. - Москва : Издательство МГУ, 2004. — 144 с.

13. Леви В.Л. Ошибки здоровья / В.Л. Леви. - Москва : ООО «Торобоан», 2004. — 274 с.

14. Yetley E.A. Multivitamin and multimineral dietary supplements : definitions, characterization, bioavailability and drug interactions / E.A. Yetley // Amer J Clin Nutr. — 2007 . Vol. 85, N. 9.- P. 269-276.

15. Студопедія. Стан і перспективи виробництва функціональних харчових продуктів та їх роль у життєдіяльності організму людини [Електронний ресурс]. - Режим доступу : http://studopedia.org /10-139249.html.

16. Полумбрик М.О. Вуглеводи в харчових продуктах і здоров'я людини / М.О. Полумбрик. - Київ : Академперіодика, 2011. - 487 с.

17. Шемета О.О. Функціональне харчування - новий підхід до здорового способу життя / О.О. Шемета, К.М. Дожук // Ліки України. — 2015. — № 1(186). - С. 24-27.

18. Тутельян B.A. Наука о питании : прошлое, настоящее, будущее / В.А. Тутельян // Вопр. питания. - 2005. - № 6. - С. 3 -6.

19. Вернадский В.И. Философские мысли натуралиста / В.И. Вернадский / АН СССР ; сост. : М.С. Бастракова, Н.В. Филиппова, Н.Ф. Овчинников, Ф.Т. Яншина. - Москва : Наука, 1988. - 520 с. 